\title{
Models, Idols, and the Great White Whale: Toward a Christian Faith of Nonattachment
}

\author{
Jeremy R. Hustwit, Methodist University \\ "What am I that I should essay to hook the nose of this leviathan?" \\ -Herman Melville, Moby Dick
}

\begin{abstract}
The juxtaposition of models of God and Christian faith may seem repugnant to many, as models are tentative and faith aims at an abiding certainty. In fact, for many Christians, using models of God in worship amounts to idolatry. By examining Biblical and extra-Biblical views of idolatry, I argue that models are not idols. To the contrary, the practice of God-modeling inoculates Christians against one of the most seductive idols of our age: the love of certainty. Furthermore, by examining meditations upon certainty in Melville's Moby Dick and the early discourses of the Buddha, I suggest that overweening conviction is a vice that hinders rather than guarantees Christian discipleship, and that Christian faith is better defined as any or all of the following: relative confidence in propositions, faithful relationship, and a virtue of disciplined credulity.
\end{abstract}

Can we put our faith in a model? On the surface, the question is nonsensical—a paradox.

Models, at least when used in the sciences, are tentative constructs. We use models to stand in for a thing when that thing's properties are obscured. ${ }^{1}$ Faith, on the other hand, is commonly thought of as supreme confidence, which is opposed to the hypothetical restraint of models. Scientists typically are not "born again" to the Rutherford atom, nor should economists accept supply side theories as their rock and redeemer. It seems downright confused to have unassailable confidence in a hypothesis. By the same token, many Christians will find models antithetical to faith. In fact, the critic of God-modeling will surely notice a resemblance to the Judeo-Christian tradition's elder statesman of sin: idolatry. After all, God-modeling tends to be pluralistic, hypothetical, and often subversive. By examining the allegories of Melville's Moby Dick and the metaphysical reticence of early Buddhism, we will see that the resemblance is only superficial. If there is a danger of idolatry, it lies in the love of certainty. Once we jettison

\footnotetext{
${ }^{1}$ In this essay, I am assuming that models are primarily used as attempts to emulate some external reality. This is not a universal view among theologians. There are many who insist that placing models into a correspondence relation with an objective thing-in-itself is to buy into a discredited subject-object dualism. For arguments for and against my assumption, see "Can Models of God Compete?" in this volume.
} 
certainty as the goal of Christian discipleship, it appears that models of God are actually boons to the faithful.

\section{The Varieties of Idolaters}

For better or worse, models have been employed throughout the history of Christianity. We need only to look at the controversies embroiling the early Church to see, for example, Trinitarian models of God side by side with Arian Binitarian, Gnostic Ditheistic, Adoptionist, and Sabellian models. Despite their esoteric labels, these models defined the thoughts, prayers, and devotion of Christian lives. But they also were denounced as examples of the one sin that is sure to rouse the ire of Yahweh: idolatry. In order to decide if models of God are idolatrous, we need to determine what exactly constitutes idolatry and why it is so pernicious. Unsurprisingly, iconoclasts have not spoken with one voice on the issue, and we can tease out at least three distinct types of idolaters that may describe God-modelers.

\subsection{Whores}

The oldest accusations of idolatry involve an obligation of loyalty between two parties, and its betrayal. This is the view most commonly found in the Hebrew Bible. During the First Temple Period and subsequent exile, the notion of a binding covenant between God and Israel was central to Hebrew religion. Furthermore, this covenant was fulfilled by Israel's performance of rituals. The blistering criticism of the prophets rarely focused on incorrect beliefs, or improper sentiments. Actions - usually sacrifices - were how Israel was to remain faithful, and actions 
were how Israel could betray God. As a result, Israel's relationship with God was described by Hosea, Ezekiel, and Jeremiah as an adulterous marriage:

But you trusted in your beauty, and played the whore because of your fame, and lavished your whorings on any passer-by.... You also took your beautiful jewels of my gold and my silver that I had given you, and made for yourself male images, and with them played the whore... (Eze 16:15, 16:17)

This earliest notion of idolatry applies only to actions performed before physical representations of foreign deities. The sexual comparison is unmistakable. The offense lies in the betrayal of loyalty owed to God, which is parallel in many ways to the loyalty expected in a marriage.

The prospect of betraying God with ritual worship only makes sense in a monolatrous system, in which other Gods are admitted to exist, but are prohibited. One would have to make a conscious decision to petition a deity other than Yahweh. So, by the fifth century BCE, when strict monotheism's victory was nearly complete, the salience of the betrayal model had waned. Furthermore, God-modeling today tends to be an imaginative task more than anything. The abstractions of modern theologians are fashioned with words, not wood or stone. Even if today's God-modelers did propitiate physical idols, those who think of models of God as metaphors for a single divine being would not necessarily be betraying God, as their worship is aimed at the one true God, albeit by means of diverse symbols. Contemporary God-modelers modelers may be many things, but they are not, by definition, whores. "Ritual betrayal," however, are not the last words in idolatry, and God-modelers are still under suspicion. 


\subsection{Fools}

In late antiquity and the early medieval period, idolatry, in concept and practice, was internalized. Worship was directed at ideas rather than golden statues. But perhaps this is more dangerous. If our ideas fail to match the reality of God, then many theologians argue we have made an idol out of our misconceptions. If so, should we be held accountable for their beliefs as well as their actions? Jewish philosopher Maimonides thinks so. He argues that any language about God is to be condemned because it either a) anthropomorphizes God into having a body and/or psyche, or b) falsely divides God into a multiplicity by means of the subject-predicate structure of language (Halbertal and Margalit 1998; Maimonides 1956). God, according to Maimonides, is so transcendent that any positive language about God, including mental language, must be false. A significant portion of Christians may agree with Maimonides and go so far as Calvin, who exclaims that human speculation about God's nature, i.e. constructing models of God, is "folly, nay madness," (Calvin 1975, 100).

It's important to point out two crucial features of models that undermine Calvin's charges of folly and madness. First, it is almost certainly true that our models of God, despite our best efforts, fail spectacularly to capture God's essence. Where the overzealous iconoclasts see the distance between a model and reality as an error, the truth is that this distance is what allows modelers to resist idolatry. The term "models" calls attention, like a blinking neon sign, to that gap between our metaphors and God's reality. A model is a self-conscious admission that language, at least for now, fails to capture reality. Furthermore, the label of "model" is an agonist, which continually refreshes the tension between every metaphor's tenor and vehicle. ${ }^{2}$ It

\footnotetext{
${ }^{2}$ For an in-depth theory of metaphor based on the tensive interaction between tenor and vehicle, see Paul Ricoeur, "Metaphor and the Semantics of Discourse," The Rule of Metaphor (Toronto: University of Toronto Press, 1977), $65-100$.
} 
preserves against the gradual death of theological metaphors. Metaphors like "Unmoved Mover," and "Poet of the Universe," when labeled as models, are preserved as hypothetical constructs. ${ }^{3}$ Those who self-consciously model God are reminded again and again that their constructs will always fall short of ultimate reality. As long as these metaphors are wedded to the category of "models," they cannot collapse into dead idols.

Second, the drive to innovate is inherent in the use of models. After all, if we thought a model were perfect, it would cease to be a model. So, models proliferate and invite revision. The inherent plurality of God-modeling draws attention to the limitations of each model. That irritating grain of uncertainty, which pushes speculation ever onward, also prevents the petrifaction of fresh ideas. It seems then, as long as models are self consciously labeled as such, cognitive error is hardly a danger. The distance between model and Truth is essential to the very concept of a model.

These two considerations imply that most Christians who use models in their devotions will not mistake those models for divine reality, and thus fall into idolatrous error. But even if they did, there are good reasons to believe that foolish beliefs about God are not, in fact, grave. Many models of God that play up God's mystery and transcendence suggest that accurate knowledge of God is difficult, if not impossible, for humans. Many religious disputes cannot be settled by natural revelation nor by scripture. This ambiguity is multiplied by hermeneutical insights about the profound differences in the way individuals interpret the world. Expecting humans to adhere to orthodoxy is a fight against entropy—not just herding cats, but expecting cats to herd themselves. The unlikelihood of consensus is not necessarily a reason to abandon it,

\footnotetext{
3 "Holy Trinity," for most Christians, has been robbed of its status as model, and in its demotion to orthodoxy, has lost the creative tension between tenor and vehicle that enriches and multiplies its meaning.
} 
but it does prompt some critical examination, and though there is insufficient space to argue it here, it seems the primary injunctions of the Gospels have little to do with correct belief.

\subsection{Philistines}

If our culture no longer struggles with ritual infidelity, and the specter of error has lost its teeth, we must look elsewhere for idolatry. Many have construed idolatry as a problem with values rather than propositional beliefs - a matter of misvaluation. When we confuse a means for an end, or mistake a limited good as the Final Good, we have made an idol of it. A church leader who spends millions of dollars in donations on a new bowling alley may be an idolater. The bowling alley has become an idol, as the minister values it more than other, higher goods. It is not hard to imagine thousands of variations on this theme, in which our projects capture more and more of our attention until they eclipse what should be our ultimate concern. Misvaluation, unlike definitions based on betrayal or error, seems to really capture the existential struggle faced by Christians in the post-industrial West.

Does God-modeling warp the values and priorities of Christians? No, models of God will largely reflect the values of the modeler. But if there is an assertion of value implicit in modelbased theology, it an aversion to one of the most seductive and misvalued idols of our age: the love of certainty. In this respect, God-modeling actually subverts idolatry.

\section{The Danger of Harpoons}


In our exploration of God-modeling, it may help to turn our attentions to the sea. Moby Dick, Melville's famous allegory of an obsessed whaler chasing after a white sperm whale, is a striking meditation upon holding on and letting go, of hubris and humility, of attachment and equanimity. If there is one man who can speak to us of idols, attachment, and life out of balance, it is Ahab.

Melville's allegory seems clear enough. As the whaling vessels venture out into the chaotic waters in pursuit of Biblical leviathans, they parallel our religious impulses, perpetually fishing bounty up from the murky depths. The whale is God, or rather every whale is a model of God. The science of whales and whaling is theology. Ishamel even cites whale experts, who lament the difficulty of constructing a systematic cetology, as there is an "impenetrable veil covering our knowledge of the cetacean," and an "unfitness to pursue our research in unfathomable waters," (Melville 1993, 109). There is clearly a tension between the desirability of these submerged beasts, and the mystery that surrounds them. We crave them despite (because of?) their obscurity.

In the quest for god-whales, less heroic men on firm ground make do with their own fabrications. Father Mapple, for instance, tries to convince his congregation that Jonah shows "true and faithful repentance," when in fact Jonah only submits after God crushes him physically and emotionally—quite a dubious reading. Mapple's sophistry is paralleled by Queequeg, who spends the sermon whittling away at the idol in his pocket in order to give it a more pleasing appearance (Melville 1993, 39, 41). As Lawrance Thompson notes, each manipulates his separate God until it suits him-Mapple uses rhetoric while Queequeg uses a jackknife. (Thompson 1952, 164). The implication is that all religion involves a degree of artifice. Jean Calvin, official theologian of New England whalers, agrees, observing, "man's nature, so to speak, is a perpetual factory of idols," (Calvin 1975, 108). Calvin would have us rely on 
unsullied revelation as opposed to the madness of speculation. But Melville's point is that even Biblical revelation goes through the meat grinder of our perspectives and interests- for better or worse. We cannot help but interpret God's nature according to a complex array of criteria, both conscious and unconscious.

Ahab however, has no patience for the safe accommodation of human speculation. He strikes out beyond the pale, into the chaos, to dominate the one whale that is either principal or agent of the malevolent God. In the beginning of the voyage, Ahab is reclusive, but as the voyage progresses, both nature and other whalers feed him rumors and hints of his prey, and his obsession is exacerbated until in a fiery climax, he taunts a violent lightning storm, and demands to "be welded" with the "unsuffusing thing beyond," (Melville 1993, 423). Of course, his demand is his doom, as Ahab does eventually meet with the whale, but is yanked overboard by the ties that bind him to the harpooned object of his obsession.

Most literary critics locate Ahab's tragic flaw in his desire to transcend mortal limitations and know the unknowable, and this is surely one layer of meaning in the tale. But perhaps the object of Ahab's quest was not the problem. Perhaps it was the tenacity with which he pursued it. After all, not every whaler who wrestles a leviathan from the deep meets an untimely end. Instead, what sets Ahab apart from other whalers is his pathological desire- his obsession. Ahab is not doomed because of his mystical streak, seeking that which is hidden beyond common appearances. Ahab's doom is his idolatrous conviction, grown monstrous. As his preoccupation is fed, it masters him, leads to an imbalance in character, and undermines his moral obligation to provide for the safety of his crew. 
Ahab is an object lesson to the theologian: suffering awaits those who lash themselves too securely to one model. The obscurity of God's reality can cause anxiety and rage, and there is something seductive about the idea of unsullied revelation. But our desire for truth, like any other desire, can burgeon into malignancy. When we get too attached to one model in particular, the self becomes parasitic upon the model, and we have become Ahab. Absolute certainty causes imbalance when our convictions work for us. When our chosen model is sunk, which may be inevitable, our attachment to it drags us down as well. Moby Dick shows us that if there is an idol to be feared, it is not the constructive artifice of Mapple and Queequeg - there is no alternative to that. The falsest idol is overweening conviction.

\section{An Unsteady Raft}

If reflection upon models of God pushes us from the love of certainty, then what alternative is left? Should we remain beatifically muddled, refusing to take any position? The Christian tradition overflows with expertise in cementing beliefs in place, but when it comes to mental flexibility, we often find ourselves flailing. The temptation is to assume the only alternative to attachment is its opposite: apathy. This, however, is a false dilemma, and our Buddhist friends can help us balance engagement with nonattachment to models of God.

Early Buddhism is unique in that it is perhaps one of the only religions that deliberately avoids metaphysical speculations, which are labeled "opinionated views" by the Buddha. ${ }^{4}$

\footnotetext{
${ }^{4}$ The distrust of speculation did not last long and Abhidharmika schools quickly arose. These schools used the early discourses to construct what appear to be systematic ontologies based on the Buddha's teachings. Both Buddhist reformers and contemporary scholars disagree as to whether the Abhidharmika schools were producing "opinionated views" or not. Charles Goodman, for instance, argues that Abhidharma was the construction of a minimally defensible ontology of the ultimate constituents of reality, (Goodman 2004). Edward Conze, on the other hand,
} 
Questions about such views - the nature of the self, cosmos, and the afterlife - were asked of the Buddha again and again, who refused to comment. On one occasion, a young monk by the name of Malunkyaputta decided to abandon the Buddha's teachings because the Buddha would neither confirm nor deny opinionated views. The Buddha's reply:

"Just as a person — having been pierced by an arrow thickly smeared with poison, and his friends and relatives, having procured a surgeon-might speak thus: 'I will not have this arrow withdrawn until I know whether the person who wounded me is either a nobleman, a Brahmin, a merchant-farmer, or a worker... has a certain name and a certain clan... is tall or short or medium height... This person would still be ignorant of those things, and then that person would die." (Cula-malunkya Sutta, 429)

Here, the Buddha warns against pursuing opinionated views because they "are not useful in attaining the goal," which is to escape the bondage of suffering (Cula-malunkya Sutta, 431). Knowing the truth about metaphysical matters is neither sufficient nor necessary for achieving salvation. In fact, attachment to opinionated views is listed as one of the primary causes of suffering, along with attachment to vows and attachment to material objects. Every conviction becomes "a jungle of views, a wilderness of views, a wriggling of views, a writhing of views, the fetter of views, bringing suffering, vexation, despair, and agony,” (Aggivacchagotta Sutta, 486). The more we invest in convictions, the more we resemble a convict.

Opinionated views are believed to cause suffering for at least two reasons. First, those who crave final answers are looking for permanence and stability in a world that affords none. The Buddhist conception of the world is one of profound impermanence. Any theological doctrine held with finality tries to nail down and define a reality that will not hold still. The result is always disillusionment and sometimes worse. Even if we do not accept the teaching of 
impermanence, which is by no means alien to the Christian tradition, every individual's finite perspective achieves the same effect. No matter how adequate a model of God we produce, it will eventually be found lacking. ${ }^{5}$ This is especially true given the problem of agreeing on what counts as an adequate model of God.

Second, the very act of taking a stand for a view is an ego-reinforcing action. This is true on the level of everyday vice—-being right tends to inflate us with conceit, especially when others are so very, very wrong. But attachment reinforces ego on a more radical level. The whole game of "truth versus error" is predicated upon an ontology of permanent selves who enjoy the future benefits of knowledge and avoid the stigma of falsehood. Though we tend to glorify the quest for truth and knowledge as a noble cause, it also is a highly individualistic pursuit. Knowledge benefits the self first and is only shared afterwards. Furthermore, the game of knowledge acquisition presupposes that the self is identified with knowledge, and both are opposed to and pitted against the objects of knowledge. These dualistic currents run deep and subtle, and contribute to feelings of alienation and anxiety—especially when the object of knowledge is also a means of salvation. These two critiques present a radical challenge to Christianity: if we define faith in the traditional way —as the cultivation of unassailable convictions about God — then faith looks to be spiritually damaging, and we must abandon it or redefine it.

At this point, some may object that we have imported entirely too many Buddhist teachings and that these criticisms hold no water for Christians, who among other things, accept the existence of an enduring self. To these objectors, we must point out that Buddhist and

\footnotetext{
${ }^{5}$ Even if a verbal model were produced that corresponded perfectly with God, verification of that correspondence would still elude us. How would we know? The modeling process would drive us past the truth, requiring some future U-turn.
} 
Christian teachings are not entirely incommensurable on the self's substantiality. The notion of kenosis, or self-emptying, has long served Christians as a description of both God's nature, Christ's significance, and an ethical ideal for humanity. ${ }^{6}$ Perhaps those who deny the existence of the self and those who believe it exists but should be subverted might share spiritual pointers. Even those Christians who anticipate the soul's resurrection may recognize the value of egodiminishing practices, including nonattachment to opinionated views.

We should be careful, though, to distinguish between the attachment to views and the holding of views. ${ }^{7}$ The goal is not to flush away all judgments and sit befuddled in a haze of indecision. The danger lies in the attachment, not in the view. Views can be held tentatively and without finality. We all have the experience of using a working hypothesis. The Buddha himself puts forward metaphysical teachings like the impermanence of all things, the nonexistence of the self, and the dependent origination of all things. These teachings are offered in a spirit consistent with the norm of nonattachment. Another parable unpacks the way to hold views without clinging to them. A monk is travelling and encounters a wide and treacherous body of water. With no other means of getting across, the monk gathers leaves and sticks to construct a raft, which safely ferries him across. Now that he is on the other side, should he heft the raft onto his shoulder and carry it with him all of his days? No, the raft is for using, not for reassurance, or valuable for its own sake. (Alagadupama Sutta, 134-135). The Buddha explains that teachings

\footnotetext{
${ }^{6}$ See Mark 8:34-35, Luke 14:25-33, Jn 12:24, Gal 5:24, Col 3:3-7, Rom 6-8, Rom 12:1-2, etc. Also, Thomas J. Oord's The Nature of Love: A Theology (New York: Chalice Press, 2010) is a good recent example of Christian kenotic theology. For kenotic parallels to anatman, see Masao Abe, "God, Emptiness, and the True Self," The Buddha Eye, ed. Frederick Franck (New York: Crossroad, 1982), pp. 61-74; and David Loy "A Zen Cloud? Comparing Zen Koan Practice with The Cloud of the Unknowing" Buddhist-Christian Studies 9 (1989), 43-60.

${ }^{7}$ Along the same lines, the Buddhist criticism of subject-object dualism referenced above pertains to the integration of knowledge and selfhood. But this need not obliterate the tensive opposition between a "subject's" confidence in a model and the divine reality. If our subjects and objects are softened and made porous to each other, and beliefs are only loosely associated with the personality, then suffering is reduced.
} 
and opinionated views have instrumental value, but one must maintain a critical distance from them while using them as tools. The correct disposition is one in which belief and skepticism are entertained simultaneously.

\section{From Dead Idols to Living Faith}

In sum, Ahab's idolatrous madness and the Buddha's equanimity suggest that traditional Christian faith, when understood as unassailable conviction, is spiritually unprofitable. This is so because clinging to belief a) ignores our own epistemic limitations, b) precludes novel revelations about a mysterious and inordinately complex God, c) fuels the egotism of being right while others are wrong, and d) reinforces the alienation between self and other. Faith-asconviction, in fact, becomes an idol for many people in the sense that possessing the "correct" beliefs about God has become more important than the moral and existential injunctions of Christ's ministry. By way of constructive conclusion, I offer three rehabilitated models of faith that Christians may find useful.

\subsection{Faith, Hypothetically}

One way to recover the notion of faith is to insist that confidence and uncertainty are not mutually exclusive. That is, we have relative degrees of confidence in all sorts of propositions. It is raining right now and I am very confident it will continue to rain. My relative confidence is based on the accumulation of evidence: the testimony of experts, the appearance of the sky, and so on. Likewise, I am not very confident at all that the Punjab cricket team will win the Ranji 
trophy. Because I know next-to-nothing about how the game of cricket is played, much less India's teams, I cannot say one way or the other. Perhaps Christian doctrine ought to be maintained on a scale of relative confidence as well.

Philosophers of logic and science have developed apparatuses to assign probabilities and make comparative judgments among empirical claims; we can develop an analogous apparatus for religious claims. ${ }^{8}$ Here, models of God could be evaluated with respect to explanatory power, predictive fruitfulness, internal coherence, aesthetic appeal, or even existential salience. Thus, models of God would be, as Wesley Wildman observes, placed in a "non-decisive rational landscape," which allows comparative judgment, but no final decision, (Wildman 2006, 189).

Thorough critics may point out, however, that although this approach remedies the dangers of epistemic hubris and theological stagnation (the aforementioned vices a and b), it really just exchanges one type of belief (the certain) for another (the best explanation). That is, it is still possible to be attached to our best explanations, as fallible as they are. For example, I could still feel proud that my model of God is more coherent than my neighbor's sorry excuse for a model, which she doesn't even realize is only a model! Furthermore, replacing certainty with nondecisive rationalities could actually exacerbate the alienation felt by the benighted believer. Without a corresponding change in how one values beliefs, reigning in our epistemic expectations could cause anxiety or even despair at the obscurity of the divine nature.

\subsection{Faithfulness}

\footnotetext{
${ }^{8}$ For an excellent exposition of what this would look like, see Wesley J. Wildman, "Comparative Natural Theology," American Journal of Theology and Philosophy 27:2-3 (2006), 173-190.
} 
A second model broadens faith from the category of belief to a temporal integration of inner and outer states. That is, faith is more properly an evolving pattern of moral decisions and behaviors than the compartmentalized pursuit of propositional assent. John B. Cobb, Jr. and David Lull argue for a version of this in their commentary on Paul's letter to the Romans. They argue that Paul's use of pistis means more than just confident assent to this or that doctrine. Pistis is a relation between two persons that involves trust, confidence, and corresponding action. Cobb and Lull translate pistis as "faithfulness" to indicate the broader sense of the term (Cobb and Lull 2005). Ahab demonstrated an abundance of faith, i.e. confidence that the whale was either an agent or principal of God's malevolence. Ahab however, did not demonstrate faithfulness. He did not trust the whale or God, and arguably did not trust his own crew. Nor did Ahab act faithfully to God, whale, or crew; his maddening conviction blinded him to their needs. Faithfulness presupposes community, and Ahab was cut off from faithfulness by his faith.

Of course, the specter of egophilia can be found in the realm of action and sentiment as well as belief. The Buddha warns against attachment to precepts and vows as much as he warns of attachment to views. But perhaps the point is that genuine faithfulness is oriented toward the well-being and principles of the other to whom one is related. Genuine faithfulness is not a selfaggrandized dedication to veganism or celibacy, but a dedication to something beyond the ego, and this selfless dedication subverts both the attachment and its effects.

It should be noted that this model of faith fits better with some models of God than others - more personal and revelatory models of God facilitate a relationship of faithfulness. It is difficult to begin a relationship with being itself. More mysterious, transcendent and nonpersonal models of God will be less likely to inspire faithfulness. 


\subsection{Virtuous Discipline}

It may also be helpful to conceive of faith as a theological virtue. Classical virtues are defined as habits of character - a propensity to act in certain ways in certain situations. Furthermore, virtues are a "golden mean" between an extreme of excess and an extreme of deficiency. Courage, for example, is the mean disposition between cowardice and foolhardiness. Perhaps faith, as a virtue, concerns when and to what degree we make up our minds. Some of us have an excessive propensity to form judgments, with a mind like a bear trap — it snaps shut easily and is difficult to reopen. Others have difficulty forming judgments at all and refuse to take positions about anything. Faith, then, would be the mean between these two extremes. It is situated between conviction and skepticism. Inspired by the man who tells Jesus, "I believe, help my disbelief," the faithful hold together belief, suspicion, wonder, and ignorance (Mk. 9:24). Conviction is easy. So is debilitating skepticism. It takes emotional and intellectual discipline to live life in the tension between a model and a mystery — an answer and a question_—without backsliding into the easy extremes. Models of God exercise this discipline while dogma does not.

The above models of faith are not mutually exclusive. In fact, there is more than likely overlap between them. Nor does one strike me as the best hypothesis, the most faithful to God, or the most virtuous. For now, it must be enough to argue that models are not idols, but the craving of certainty is an idol. Upon examination, it seems that models of God, in their resistance to finality, are more likely to facilitate than to sabotage Christian discipleship. 


\section{Bibliography}

Abe, Masao. 1982. "God, emptiness, and the true self," in The Buddha eye. Ed. Frederick Franck. New York: Crossroad Publishing.

Calvin, Jean. 1975. Institutes of the Christian religion, vol. 1. Ed. John T. McNeil. Trans. Ford Lewis Battles. Library of Christian classics. Philadelphia: Westminster Press.

Cobb, John B., Jr., and Lull, David J. 2005. Romans. Chalice Commentaries for Today. St. Louis: Chalice Press.

Conze, Edward. 1959. Buddhism: Its essence and development. New York: Harper Torchbooks.

Goodman, Charles. 2004. "The treasury of metaphysics and the physical world." Philosophical quarterly 54.4: 389-401.

Halbertal, Moshe and Avishai Margalit. 1998. Idolatry. Cambridge, MA: Harvard University Press.

Holder, John J., ed. and trans. 2006. Early Buddhist discourses. Indianapolis: Hackett Publishing.

Loy, David. 1989. "A Zen cloud? Comparing Zen koan practice with The Cloud of Unknowing." Buddhist-Christian studies 9, 43-60.

Maimonides, Moses. 1956. The guide for the perplexed. Tr. M. Friedlaender. $2^{\text {nd }}$ ed. New York: Dover Publications.

Melville, Herman. 1993. Moby Dick. New York: Barnes and Noble Books.

Oord, Thomas J. 2010. The nature of love: a theology. New York: Chalice Press.

Ricoeur, Paul. 1977. "Metaphor and the semantics of discourse," in The rule of metaphor. Toronto: University of Toronto Press, 65-100.

Thompson, Lawrance. 1952. Melville's quarrel with God. Princeton: Princeton University Press.

Wildman, Wesley J. 2006. "Comparative natural theology," American journal of theology and philosophy 27:2-3, 173-190. 